\title{
Perbaikan Manajemen Pakan Silase untuk Keberlanjutan Usaha Peternakan Sapi di Era New Normal pada Kelompok Ternak Bago Mulyo
}

\author{
Rizki Amalia Nurfitriani ${ }^{1 *}$, Nur Muhamad ${ }^{2}$, Mira Andriani ${ }^{3}$, Niswatin Hasanah ${ }^{4}$ \\ 1,2,3,4 Jurusan Peternakan, Politeknik Negeri Jember \\ ${ }^{1}$ ranurfitriani@polije.ac.id, ${ }^{2}$ nurmuhamad@polije.ac.id, ${ }^{3}$ andriani@polije.ac.id, , ${ }^{4}$ niswatin_hasanah@polije.ac.id
}

\begin{abstract}
Feeding independence is one of the target achievements desired by every farmer. One of them is the Bago Mulyo livestock group. The Bago Mulyo livestock group is a livestock group located in Gumukmas District, Jember Regency. Several problems of the Bago Mulyo Livestock Group which reduce production by 5\% because the prices of production facilities (seeds, fertilizers, pesticides, and feed) are expensive and the distribution is not smooth; the need for food will increase by 5\% due to panic buying and food supplies. The distribution of feed was not optimal, making farmers have to find solutions so that feed ingredients are still available. One solution is to utilize existing feed ingredients and maintain their feed quality until they are available throughout the year, namely by silage method. The implementation of the service consists of several activities, the first was coordination with the head of the Bago Mulyo livestock group, purchased silage materials, simulated modified silo tools, implementation of community service, and surveying the results of community service activities. The results of the community service survey which have shown that 100\% of farmers who participate in the service activities understand silage technology with the addition of silo modification from previously only $43 \%$ who understand silage technology. The conclusion is an increase in understanding of silage technology which is one of the indicators of support for the service team in carrying out service activities for the Bago Mulyo Livestock Group, so that this technology can be applied properly for the sustainability of the cattle business in the Livestock Group.
\end{abstract}

Keywords : Feed, Beef Cattle, Silage, Silo

Abstrak

Kemandirian pakan merupakan salah satu target capaian yang diinginkan oleh setiap peternak. Salah satunya adalah kelompok ternak Bago Mulyo. Kelompok ternak Bago Mulyo merupakan kelompok ternak yang berada di Kecamatan Gumukmas, Kabupaten Jember. Beberapa kendala yang dialami oleh Kelompok Ternak Bago Mulyo yaitu menurunkan produksi sebesar 5\% karena harga sarana produksi (benih, pupuk, pestisida, dan pakan) mahal dan distribusinya tidak lancar; kebutuhan pangan akan meningkat 5\% karena panic buying dan masyarakat menyetok pangan. Adanya pendistribusian pakan yang tidak optimal, membuat peternak harus mencari solusi agar bahan pakan tetap tersedia. Salah satu solusinya adalah dengan memanfaatkan bahan pakan yang ada dan menjaga atau mempertahankan kualitasnya hingga dapat tersedia sepanjang tahun yaitu dengan pengawetan pakan metode silase. Metode kegiatan terdiri dari tahapan persiapan, pelaksanaan, dan evaluasi. Pelaksanaan pengabdian terdiri dari beberapa kegiatan yaitu pertama kegiatan koordinasi bersama ketua kelompok ternak Bago Mulyo, pembelian bahan silase, simulasi alat silo modifikasi, pelaksanaan pengabdian, dan survey hasil kegiatan pengabdian. Hasil survey kegiatan pengabdian yang telah dilaksanakan menunjukkan bahwa $100 \%$ peternak yang mengikuti kegiatan pengabdian memahami teknologi silase 
dengan penambahan modifikasi silo dari yang sebelumnya hanya $43 \%$ yang memahami teknologi silase. Kesimpulan dari kegiatan ini yaitu adanya peningkatan pemahaman mengenai teknologi silase dan cara pembuatan silase pada Kelompok Ternak Bago Mulyo, menjadi indikator keberhasilan tim pengabdian dalam menjalankan kegiatan pengabdian di Kelompok Ternak Bago Mulyo, sehingga teknologi ini dapat diterapkan dengan baik untuk keberlanjutan usaha ternak sapi pada Kelompok Ternak tersebut.

Kata Kunci: Pakan, Sapi Potong, Silase, dan Silo

*Penulis Korespondensi: Rizki Amalia Nurfitriani

\section{PENDAHULUAN}

Kemandirian pakan merupakan salah satu target capaian yang diinginkan oleh setiap peternak. Salah satunya adalah kelompok ternak Bago Mulyo. Kelompok ternak Bago Mulyo merupakan kelompok ternak yang berada di Kecamatan Gumukmas, Kabupaten Jember. Adanya pandemi Covid-19 membuat usaha peternakan khususnya di kelompok ternak Bago Mulyo mengalami penurunan produksi, khususnya dalam memproduksi pakan untuk kebutuhan ternak sehari-hari. Hal ini disebabkan oleh adanya larangan dari pemerintah terkait berpergian ke luar daerah. Larangan bepergian ke luar daerah ini tertuang dalam Surat Edaran yang dikeluarkan oleh Direktorat Jenderal Peternakan dan Kesehatan Hewan Nomor 00964/SE/PK.320/F/02/2020 (Direktorat Jenderal Peternakan dan Kesehatan Hewan, 2020). Larangan tersebut menyebabkan distribusi pakan baik dari luar ataupun dalam daerah menjadi tidak optmial. Dari data prakiraan produksi dan kebutuhan pangan pokok strategis yang dikeluarkan Badan Ketahanan Pangan, Kementerian Pertanian dengan asumsi dengan adanya penyebaran COVID19 akan berakibat beberapa hal. Pertama, menurunkan produksi sebesar 5\% karena harga sarana produksi (benih, pupuk, pestisida, dan pakan) mahal dan distribusinya tidak lancar. Kedua, kebutuhan pangan akan meningkat 5\% karena panic buying dan masyarakat menyetok pangan (Hermanto, 2020). Adanya pendistribusian pakan yang tidak optimal, membuat peternak harus mencari solusi agar bahan pakan tetap tersedia.

Salah satu solusinya adalah dengan memanfaatkan bahan pakan yang ada dan menjaga atau mempertahankan kualitasnya hingga dapat tersedia sepanjang tahun. Salah satu bahan pakan yang cukup melimpah keberadaannya di wilayah Jember adalah Limbah Edamame. Usaha edamame menghasilkan 12 ton limbah kulit edamame setiap harinya (Syahniar and Subagja, 2018). Kandungan nutrient limbah kulit edamame diantaranya 97,9\% BK, 10,5\% PK, 3\% LK, 29,2 SK, dan 5,2\% Abu (Syahniar and Subagja, 2018). Tingginya kandungan nutrient limbah edamame ini penting untuk diolah sebagai bahan pakan alternatif untuk ternak khususnya ternak ruminansia dalam hal ini sapi dan kambing. Upaya untuk menjaga agar limbah edamame ini tetap tersedia sepanjang tahun adalah dengan mengawetkan limbah tersebut. Metode yang dapat dilakukan untuk mengawetkan limbah edamame salah satunya yaitu metode silase. Ensilase merupakan metode untuk pengawetan hijauan pakan ternak yang telah digunakan secara luas melalui proses fermentasi secara alamaiah (Deaville, Givens and Mueller-Harvey, 2010). Silase berkualitas baik akan dihasilkan ketika fermentasi didominasi oleh bakteri yang menghasilkan asam laktat, sedangkan aktivitas bakteri clostridia rendah (Downing et al., 2008). Prinsip pembuatan silase adalah mempertahankan kondisi kedap udara dalam silo semaksimal mungkin.

Kondisi kedap udara dapat diupayakan dengan cara pemadatan bahan silase semaksimal mungkin dan penambahan sumber karbohidrat fermentabel (Santoso et al., 2009). Metode silase merupakan metode pengawetan bahan pakan yang dilakukan dengan prinsip fermentasi menggunakan sistem kerja mikroba. Sistem kerja mikroba yang digunakan pada silase bersifat anaerob, sehingga menjadi poin kritis dalam penerapan pembuatan silase. Sejauh ini kelompok ternak Bago Mulyo sudah mulai menerapkan metode silase dalam pemanfaatan bahan pakan lokal. Akan tetapi, silase yang dihasilkan belum optimal. Hal ini diduga karena proses silase tidak berjalan optimal, salah satunya disebabkan oleh kondisi silo yang kurang anaerob. Kondisi silo yang masih mengandung oksigen, akan mengakibatkan mikroba anaerob tidak bekerja optimal sehingga silase yang dihasilkan menjadi busuk karena adanya bakteri aerob yang menghambat kerja bakteri anaerob.

Adanya permasalahan ini, perlu dicarikan solusi agar manajemen pakan pada kelompok ternak Bago Mulyo tetap terjaga, meski di era new normal masih belum berjalan lancar mengenai pendistribusian pakan. Salah satu solusi yang dapat dilakukan adalah dengan perbaikan manajemen pakan melalui optimalisasi pembuatan silase. Perbaikan yang dilakukan adalah dengan menambahkan komponen lain yang dapat menjaga kondisi silo agar tetap anaerob. Salah satu komponen yang dapat ditambahkan yaitu pompa vakum. Penerapan 
pompa vakum dapat mengurangi kadar oksigen semaksimal mungkin.

Diharapkan dengan adanya solusi tersebut dapat meningkatkan manajemen pakan pada usaha ternak sapi potong, sehingga kelompok ternak Bago Mulyo dapat memperoleh keuntungan yang maksimal. Peningkatan manajemen pakan dapat membantu usaha peternakan tersebut.

\section{METODE}

Adapun metode yang digunakan dalam kegiatan ini sebagai berikut :

\section{a. Tahap Persiapan}

Tahap persiapan dilakukan untuk mengawali kegiatan pada program pengabdian kepada masyarakat ini. Tim dan mahasiswa melakukan sosialisasi pada anggota mitra. Kemudian, dilakukan diskusi mendalam antara Tim dengan mitra terutama anggota pengurus untuk penyamaan persepsi mengenai permasalahan yang ada.

\section{b. Tahap Pelaksanaan}

Tahapan pelaksanaan pengabdian pada kegiatan ini yaitu tahap persiapan yang terdiri dari koordinasi dengan ketua kelompok, persiapan bahan, dan simulasi alat, Selain itu, tahapan selanjutnya adalah pelaksanaan pengabdian yang dihadiri oleh $10 \%$ anggota kelompok (adanya pembatasan kerumuman) yaitu 5 orang. Pelaksanaan pengabdian terdiri dari sosialsiasi mengenai pentingnya dilakkan pengawetan pakan, dan penjelasan pengawetan pakan yang umum digunakan di Indonesia yaitu silase, setelah sosialisasi dilakukan pembuatan silase dengan metode yang mengacu pada Sadarman et al., (2019).

\section{c. Tahap Evaluasi}

Tahapan terakhir yaitu evaluasi kegiatan pengabdian yang diikuti oleh seluruh peternak yang mengikuti kegiatan pengabdian saat sosialisasi dan pembuatan teknologi silase.

\section{HASIL DAN PEMBAHASAN}

Pelaksanaan persiapan berjalan dengan baik, dimana tim pengusul melakukan kerjasama untuk membuat simulasi pembuatan silase terlebih dahulu untuk memastikan bahwa teknologi yang kita terapkan dapat digunakan dengan baik untuk masyarakat dalam hal ini yaitu Kelompok Ternak Bago Mulyo. Persiapan yang telah dilakukan yaitu penyusunan jadwal, koordinasi bersama ketua kelompok ternak Bago Mulyo, sosialisasi pelaksanaan pengabdian, survey pada kelompok ternak Bago Mulyo, pembelian peralatan untuk simulasi pembuatan komponen silo, perakitan alat silo, dan pembelian rumput dan bahan starter.

Pelaksanaan pengabdian dilakukan dengan menerapkan protokol pencegahan Covid-19 yaitu mencuci tangan, menjaga jarak, dan memakai masker. Adapun tahapan pelaksanaan pengabdian yang telah dilakukan yaitu sosialisasi mengenai pengawetan bahan pakan, pembuatan silase, dan evluasi kegiatan hasil pembuatan silase. Sosilasisasi mengenai pengawetan bahan pakan dilakukan selama 2 jam untuk memberikan pengetahuan kepada kelompok ternak mengenai pentingnya dibuat suatu program pengawetan pakan.

Sosialisasi yang dilaksanakan tim pengabdian mengenai pentingnya dilakukan pengawetan pakan dalam penyediaan bahan pakan di masa pandemi berjalan dengan baik. Hal ini terlihat dari antusiasnya seluruh peternak dari Kelompok Ternak Bago Mulyo yang hadir saat pelaksanaan sosialisasi (Gambar 1).

Adanya antusiasme dari peternak yang hadir menjadi Langkah awal untuk menerapkan teknologi yang telah dibuat oleh tim pengabdian. Hal ini dapat membantu dalam proses interpretasi dan penerapan teknologi khususnya teknologi pengawetan pakan yang dapat menjaga ketersediaan pakan di sepanjang tahun.

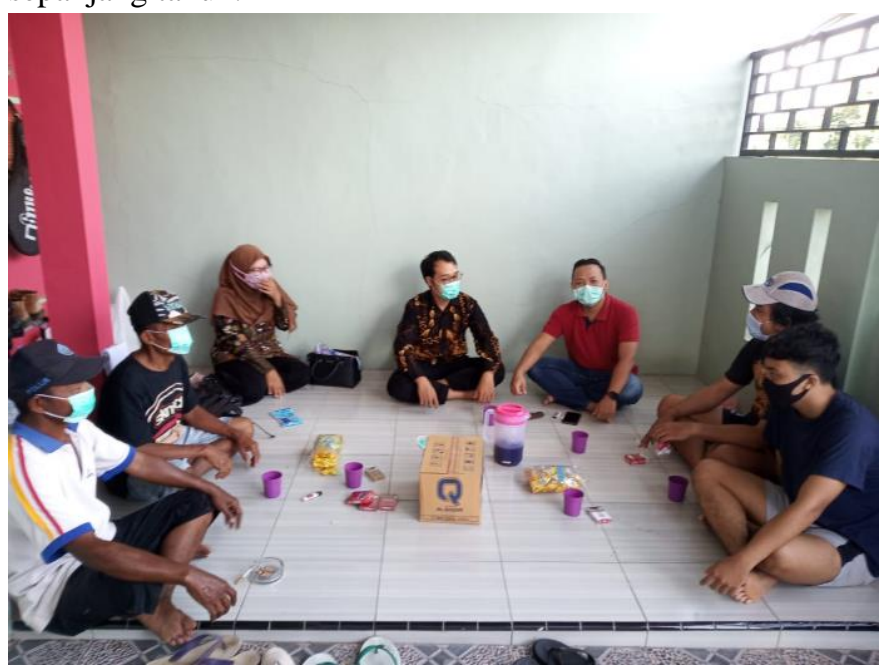

Gambar 1. Sosilasisasi Pentingnya Penerapan Pengawetan Pakan

Hasil pelaksanaan sosilasisasi diperoleh bahwa kelompok ternak selama ini hanya $67 \%$ dari yang hadir yang sudah mengetahui metode pengawetan pakan. selebihnya belum mengetahui metode pengawetan silase yang berpotensi digunakan dalam penyediaan pakan sepanjang tahun. Selain itu, diperoleh bahwa peternak tertarik untuk membuat 
pengawetan pakan berbahan dasar pakan yang tersedia di Kawasan Kelompok Ternak Bago Mulyo (Gambar 2).

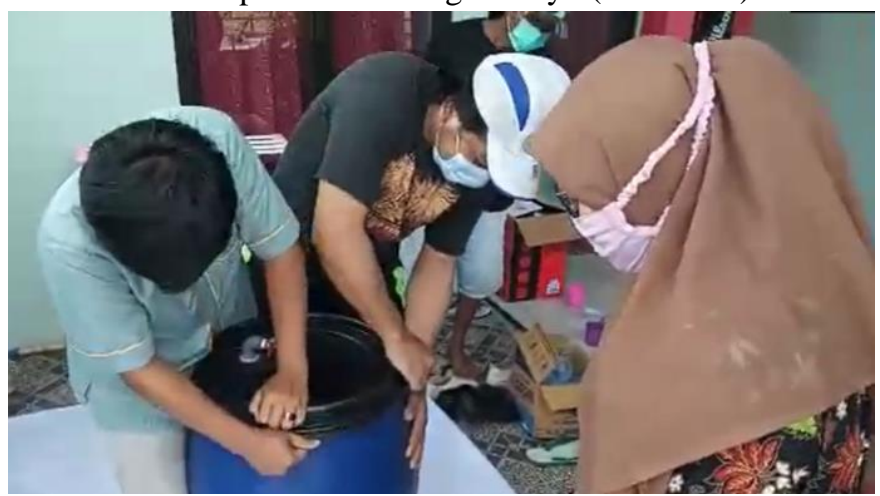

Gambar 2. Proses Pembuatan Silase

Pengawetan pakan dilakukan untuk penyimpanan atau stok pakan untuk menjaga apabila ketersediaan pakan segar habis. Metode pengawetan pakan terdiri dari 2 jenis secara umum yang dikenal dengan metode pengawetan secara kering atau disebut dengan metode hay dan merode pengawetan secara basah atau disebut dengan metode silase. Metode hay dilakukan dengan memanfaatkan sinar matahari (penjemuran) atau dapat diangin-anginkan, namun dengan syarat tempat dijadikan untuk pembuatan hay tidak lembab sehingga proses pengeringan dapat berjalan dengan baik. Sedangkan metode pengawetan silase dilakukan dengan memanfaatkan bakteri unutk mendegradasi pakan agar dapat memperbaiki kualitas pakan, serta dapat disimpan dalam jangka waktu yang lama.

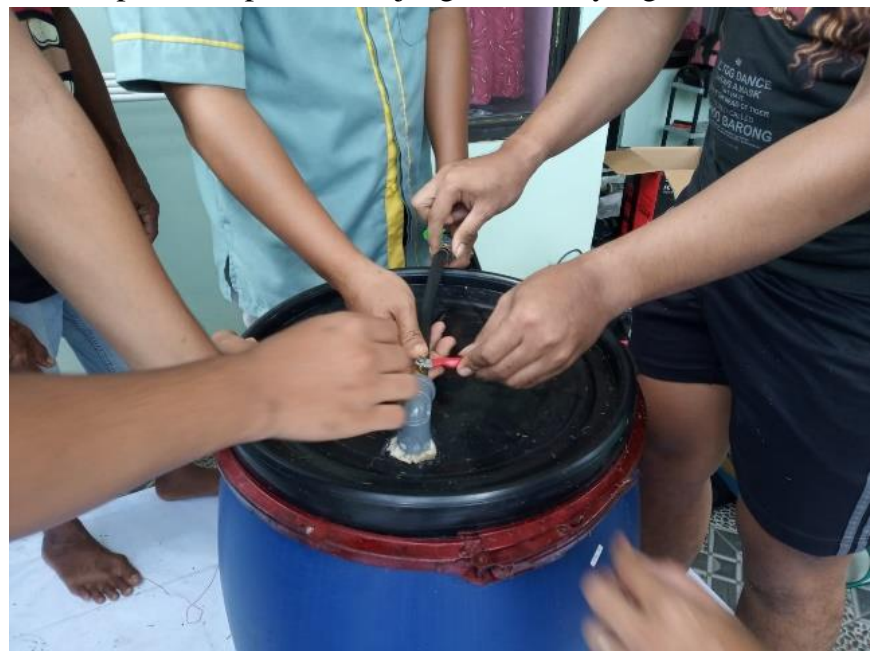

Gambar 3. Pembuatan Modifikasi Silo

Metode yang diterapkan pada Kelompok Ternak Bago Mulyo yaitu metode pengawetan Silase. Hal ini karena metode silase sudah umum digunakan di Indonesia dan kondisi cuaca di Indonesia yang saat ini fluktuatif. Pembuatan silase tersebut yaitu pencacahan rumput gajah dengan panjang sekitar $3-5 \mathrm{~cm}$, homogenisasi rumput yang telah dicacah dengan starter sebanyak 5\% dari berat pakan yang dibuat silase, pemadatan pakan ke dalam silo hasil modifikasi (Gambar 3) dengan penambahan pompa vakum.

Sebelumnya dijelaskan terlebih dahulu mengenai silo yang telah dimodifikasi serta manfaatnya untuk dijadikan dan diterapkan dalam pembuatan silase. Silo yang dimodifikasi merupakan silo yang diberikan tambahan komponen untuk meminimalisir adanya oksigen didalam silo saat proses fermentasi (Gambar 4).

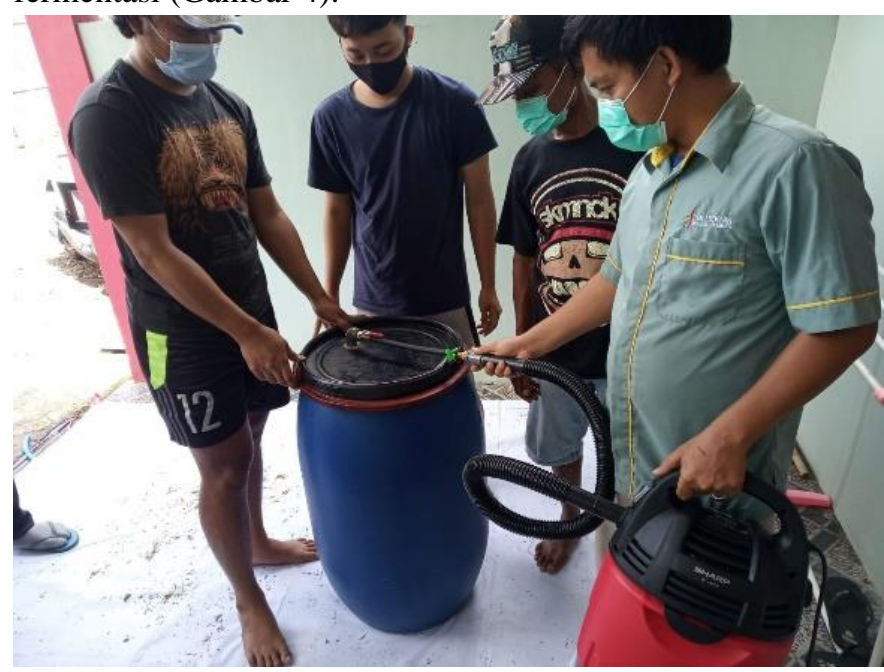

Gambar 4. Proses Vakum menggunakan Silo Modifikasi

Pembuatan silase berjalan dengan baik. Kemudian setelah pembuatan silase selesai, dilakukan penjelaskan mengenai indicator silase yang baik dan siap untuk diberikan pada ternak. Indikator bahwa silase tersebut memberikan hasil yang baik yaitu dilihat dari fisik tidak terjadi perubahan signifikan warna rumput sebelum dan setelah fermentasi, $\mathrm{pH}$ asam, ada wangi khas seperti wangi yoghurt, serta tidak berjamur (Sadarman et al., 2019).

Setelah kegiatan pengabdian selesai dilaksankan, tim pengabdian melakukan survey kembali untuk melihat konsep pepahaman kelompok ternak Bago Mulyo. Survey ini dilakukan dengan memberikan pertanyaan berupa kuisioner kepada kelompok ternak yang hadir pada saat pelaksanaan pengabdian. Adapun hasil survey disajikan pada Gambar 5. 


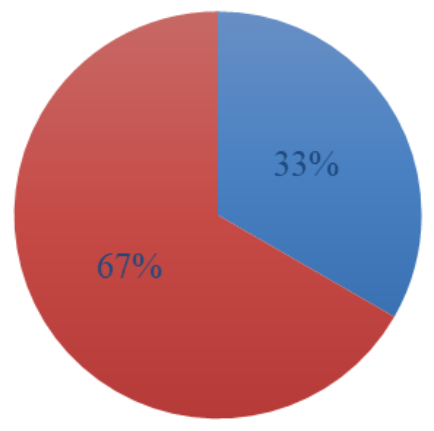

- Paham Teknologi Silase $\quad$ Belum Paham Teknologi Silase

Gambar 5. Pengetahuan Peternak tentang SIlase sebelum Pelaksanaan Pengabdian

Hasil konsep pre test dilaksanakan pengabdian menunjukkan bahwa $67 \%$ peternak belum memahami mengenai teknologi silase, sehingga hasil pembuatan silase menjadi kurang baik. Survey yang dilakukan setelah pelaksanaan pengabdian (post test)disajikan pada Gambar 6.

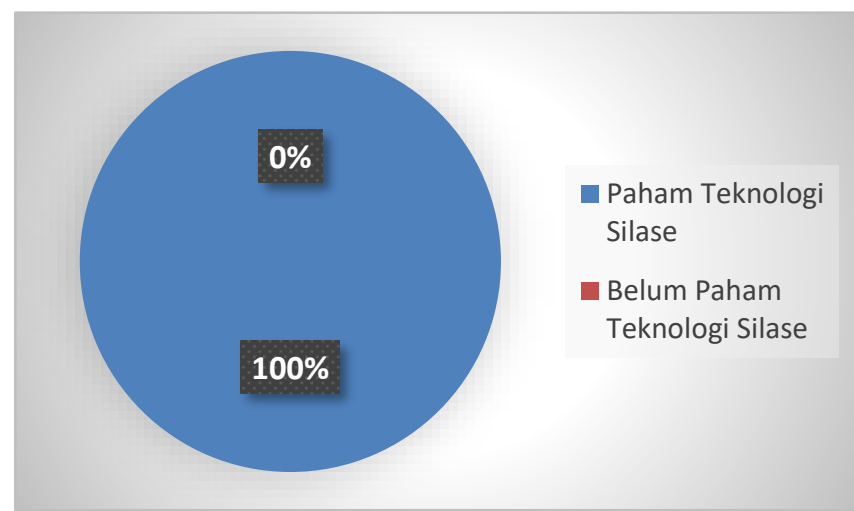

Gambar 6. Pengetahuan Peternak tentang Silase setelah Pelaksanaan Pengabdian

Hasil evaluasi post test menunjukkan bahwa $100 \%$ peternak yang mengikuti dan membuat silase memahami cara pembuatan dan evaluasi kualitas silase yang telah dibuat. Produk silase yang baik menunjukkan bahwa kegiatan pengabdian yang telah dilakukan dapat memperbaiki manajemen pakan kelompok ternak Bago Mulyo (Syahniar and Subagja, 2018), khususnya di masa pandemic Covid-19.

\section{KESIMPULAN}

Kesimpulan dari kegiatan ini yaitu adanya peningkatan pemahaman mengenai teknologi silase dan cara pembuatan silase pada Kelompok Ternak Bago Mulyo sebsear 33\%. Hal ini menjadi indikator keberhasilan tim pengabdian dalam menjalankan kegiatan pengabdian di Kelompok Ternak Bago Mulyo, sehingga teknologi ini dapat diterapkan dengan baik untuk perbaikan manajemen pakan sebagai upaya keberlanjutan usaha ternak sapi pada Kelompok Ternak tersebut.

\section{UCAPAN TERIMA KASIH}

Tim pengabdian mengucapkan terima kasih kepada seluruh pihak yang telah membantung dan memberi dukungan atas terlaksananya kegiatan pengabdian ini. Pihak-pihak yang telah membantu tim pengabdian dalam pelaksanaan pengabdian yaitu Institusi Politeknik Negeri Jember, serta Kelompok Ternak Bago Mulyo. Semoga kedepannya akan banyak program yang dapat diterapkan untuk kemajuan peternakan Indonesia.

\section{DAFTAR PUSTAKA}

Deaville, E. R., Givens, D. I. and Mueller-Harvey, I. (2010) 'Chestnut and mimosa tannin silages: Effects in sheep differ for apparent digestibility, nitrogen utilisation and losses', Animal Feed Science and Technology. Elsevier B.V., 157(3-4), pp. 129-138. doi: 10.1016/j.anifeedsci.2010.02.007.

Downing, T. W. et al. (2008) 'Effect of Water Soluble Carbohydrates on Fermentation Characteristics of Ensiled Perennial Ryegrass', Professional Animal Scientist, 24(1), pp. 35-39. doi: 10.15232/S1080-7446(15)30807-X.

Hermanto (2020) 'Buletin Perencanaan Pembangunan Pertanian', Dampak Ekonomi Penyebaran Covid-19 Terhadap Kinerja Sektor Pertanian, 2, pp. 10-14. Available at: http://perencanaan.setjen.pertanian.go.id/public/upload/fil e/20200415123744BULETIN-EDISI-KHUSUS.pdf.

Hewan, D. J. P. dan K. (2020) 'Surat Edaran novel corona virus.pdf'.

Sadarman, S. et al. (2019) 'Kualitas Fisik Silase Ampas Kecap Dengan Aditif Tanin Akasia (Acacia Mangium Wild.) Dan Aditif Lainnya', Jurnal Peternakan, 16(2), p. 66. doi: 10.24014/jupet.v16i2.7418.

Santoso, B. et al. (2009) 'Kualitas Rumput Unggul Tropika Hasil Ensilase dengan Bakteri Asam Laktat dari Ekstrak Rumput Terfermentasi', Media Peternakan, 32(2), pp. 137-144.

Syahniar, T. M. and Subagja, H. (2018) 'Peningkatan Kualitas Pakan dan Perbaikan Manajemen Produksi di PeternakanSapi Potong Bago Mulyo , KecamatanGumuk MasKabupaten Jember', Jurnal Peternakan, Politeknik Negeri Jember, pp. 87-91. 